\title{
Physico-Chemical Profile of Four Types of Honey from the South of the Republic of Moldova
}

\author{
Aurica Chirsanova, Tatiana Capcanari, Alina Boistean, Rodica Siminiuc \\ Department of Food and Nutrition, Technical University of Moldova, Chisinau, Republic of Moldova \\ Email: aurica.chirsanova@toap.utm.md
}

How to cite this paper: Chirsanova, A., Capcanari, T., Boistean, A. and Siminiuc, R. (2021) Physico-Chemical Profile of Four Types of Honey from the South of the Republic of Moldova. Food and Nutrition Sciences, 12, 874-888.

https://doi.org/10.4236/fns.2021.129065

Received: August 4, 2021

Accepted: September 5, 2021

Published: September 8, 2021

Copyright $\odot 2021$ by author(s) and Scientific Research Publishing Inc. This work is licensed under the Creative Commons Attribution International License (CC BY 4.0).

http://creativecommons.org/licenses/by/4.0/

\begin{abstract}
There are many studies that compare the quality and biological characteristics of honey with distinct geographical and botanical origins. However, the physico-chemical and biological properties of different types of honey in the same production regions are rarely mentioned. The honey used in this study: sunflower honey, rapeseed honey, manna honey and polyflora honey, came from GT "Malai C" in Taraclia village, Causeni district in the southern part of the Republic of Moldova and belonged to the flowering season of year 2020. Following the polynecological analysis, it was found that two types of honey are monofloral with a dominant pollen content of Helianthus spp. (49.15\% 93.12\%) in sunflower honey and Brassica spp. (52.17\% - 70.11\%) in rapeseed honey. Mana honey and polyflora contain several types of pollen. Thus, four types were identified in manna honey, including: Acer platanoides $(29.11 \%$ $30.11 \%)$, Quercus robur (28.67\% - 29.99\%), Rubus idaeus (21.55\% - 28.78\%), Taraxacum officinale $(22.21 \%$ - 28.76\%). Polyflora honey contains: Helianthus annuus $(24.91 \%$ - 31.11\%), Brassica napus (23.45\% - 29.18\%), Tilia (28.95\% - 31.92\%). Based on a Pfund scale, it was found that the color of the honey varied from a lighter shade for rapeseed honey (water amber $7.66 \pm$ $3.002 \mathrm{~mm}$ ) to a darker color for sunflower honey and polyflora (extra light amber $34.366 \pm 21.01 \mathrm{~mm}$ and $36.04 \pm 1.115 \mathrm{~mm}$ respectively). Spectrophotometric determination of phenolic compounds in honey samples showed that their content ranged from $38.18 \mathrm{mg} \mathrm{GAE} / \mathrm{kg}$ honey for rapeseed honey to $831.09 \mathrm{mg} \mathrm{GAE} / \mathrm{kg}$ honey for manna honey. At the same time, the flavonoid content ranged from $28.41 \mathrm{mg}$ QUE/kg honey for rapeseed honey to 151.72 $\mathrm{mg}$ QUE/kg honey for manna honey. Mana honey showed a better antioxidant activity than the other honey samples in the study (72.03\%). The reported results suggest that manna honey has the best potential and its consumption in the human diet as food with valuable biological properties can be
\end{abstract}


encouraged, despite the fact that in the Republic of Moldova it is in a small amount.

\section{Keywords}

Honey, Palynological Analysis, Physico-Chemical Indices, Penolic Compounds, Flavonoids

\section{Introduction}

Honey is a sweet, viscous substance produced by honey bees (Apis mellifera L.) [1]. The food is the only natural sweetener that people can use without processing [2] [3]. From ancient times, honey is considered an important food for Homo sapiens, and the relationship between bees and humans began in the Stone Age [4] [5]. During the evaluation of mankind, honey became an important commercial currency with which to pay for certain taxes [6] [7]. There has always been a strong link between humans and bees, and this relationship is largely based on the fact that $80 \%$ of plants are pollinated by bees [8] and today, beekeeping is becoming a key occupation for income generation, especially in countries developing [9] [10].

At the same time, the increased interest in honey is argued, in particular, by its therapeutic properties [11] [12] [13], including wound healing [14], treatment gastric ulcer [15], in preventing and combating cancer [16] [17] [18], and other. The anti-inflammatory properties of bee honey reduce the severity of lung manifestations in COVID-19 infections, which is quite important in the current context [19] [20] [21].

The Republic of Moldova has a rich tradition in terms of honey production, with an average of 4.000 tons per year, but which is mostly exported to the European Union [22]. The surfaces of the fruit plantations from the agricultural enterprises and the peasant households represent $44.323 \mathrm{ha}$, and for their pollination approximately 132.969 bee families are necessary.

At the same time, in the period 2008-2017 a slight increase in the number of bee families was reported, from 98.3 thousand in 2008 to 148.1 thousand in 2017. The cost of producing one kilogram of honey in the Republic of Moldova depends largely on the amount of honey obtained, which is closely related to climatic conditions and is in the range of $1.65-1.80$ US dollars in the case of a "normal" year [23].

Studies that highlight the quality of local honey in geographical areas of the Republic of Moldova, at the moment, are not enough. The purpose of this study was: to perform pollen analysis of four types of honey from the southern part of the Republic of Moldova; to determine chromatic and physico-chemical indices: $\mathrm{pH}$, free acidity, humidity, electrical conductivity, hydroxymethylfurfural (HMF) content; to determine the content of polyphenols, flavonoids and DDPH and to compare results obtained with data from the literature. 


\section{Materials and Methods}

All chemicals and reagents used for the analyses were of analytical quality. Reagents used for the analysis of total phenolic compounds and antioxidant tests were purchased from Sigma-Aldrich (Deisenhofen, Germany). All physicochemical methods were performed in accordance with the harmonized methods of the International Honey Commission.

\section{Samples}

The honey samples used in this study are from the following botanical origins: sunflower honey, rapeseed honey, manna honey and polyflora honey. All samples were provided from GT "Malai C" from Taraclia village (latitude: 46.5702781677246100, longitude: 29.1155548095703120, altitude: $91 \mathrm{~m}$ ), Causeni district, Republic of Moldova (Figure 1).

Samples were collected during the flowering season of 2020. During the research, the honey samples were kept in laboratory conditions, packed in sealed glass jars at a temperature of $21^{\circ} \mathrm{C} \pm 2^{\circ} \mathrm{C}$.

\section{Palynological analysis}

It was performed by microscopic analysis according to the method of Lutier and Vaissière (1993) [24].

\section{Color analysis}

The honey samples were dissolved in water $(1: 1 ; \mathrm{w} / \mathrm{v})$ and the color was determined by spectrophotometric measurement of the absorbance of honey solution at $635 \mathrm{~nm}$. The honey was classified based on color using Pfund scale after conversion of the absorbance values: $\mathrm{mm}$ Pfund $=-38.70+371.39 \times$ Abs [25].

\section{Humidity}

Mass fraction of water was determined using Honey humidity refractometer ATAGO 4422 PAL-22S, $12.0 \%$ to $30.0 \%$, acc. $\pm 0.2 \%$.

\section{$\mathrm{pH}$ measurements}

The $\mathrm{pH}$ of the samples was measured potentiometrically at $20^{\circ} \mathrm{C}$ using a pH-meter (HANNA 2211-02 pH/MV/C) bench meter with electrode holder.

\section{Acidity}

Acidity was determined by the titrimetric method. It is based on the titration of the honey sample diluted with water, with $0.1 \mathrm{n}$ sodium hydroxide in the presence of phenolphthalein as indicator.

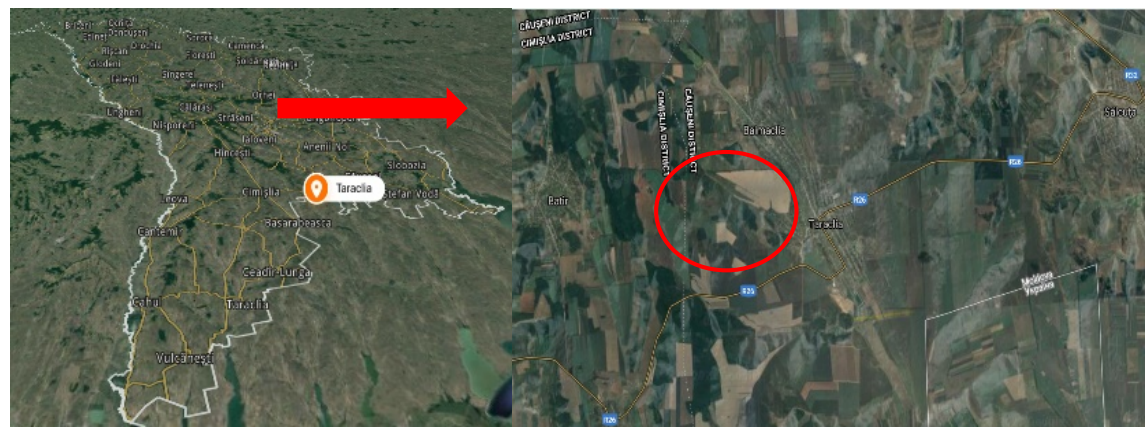

Figure 1. Geographical origin of honey samples. 


\section{Determination of diastase index}

The basis of this analysis is the determination of amylase activity. The diastase index is defined as the number of milliliters of $1 \%$ starch solution which has been converted to dextrin for one hour at $45^{\circ} \mathrm{C}$ at the optimum $\mathrm{pH}$ of amylase containing $1 \mathrm{~g}$ of honey.

\section{Hydroxymethylfurfural content}

The Fiehe reaction is based on the fact that the hydroxymethylfurfural forms with the resorcinol, in hydrochloric acid medium, a complex colored in red, whose color intensity is proportional to the quantity of the respective compound. When the Fiehe reaction is positive, the honey is considered suspicious and the deconfirmation test is further performed by determining the hydroxymethylfurfural content.

\section{Polyphenols}

Total polyphenol contents in each sample were determined using the Folin-Ciocalteu colorimetric method. The sample solution $(0.1 \mathrm{~mL})$ was mixed with $0.5 \mathrm{~mL}$ of Folin-Ciocalteu reagent and $0.4 \mathrm{~mL}$ of $7.5 \% \mathrm{Na}_{2} \mathrm{CO}_{3}$, and the absorbance was measured at $765 \mathrm{~nm}$ after $10 \mathrm{~min}$ at $37^{\circ} \mathrm{C}$. Total polyphenol contents were expressed as $\mathrm{mg}$ gallic acid equivalents GAE $/ \mathrm{kg}$ honey.

\section{Flavonoids}

The total flavonoid content was measured using the colorimetric method [26]. Honey samples in the amount of $1 \mathrm{~mL}$ were mixed with $4 \mathrm{~mL}$ distilled water. At the baseline, $0.3 \mathrm{~mL} \mathrm{NaNO}$ (5\%, w/v) was added. After $5 \mathrm{~min}, 0.3 \mathrm{~mL} \mathrm{AlCl} 3$ $(10 \% \mathrm{w} / \mathrm{v})$ was added followed by the addition $2 \mathrm{~mL}$ of $\mathrm{NaOH}(1 \mathrm{~N}) 6$ min later. The volume was then increased to $10 \mathrm{~mL}$ by the addition of $2.4 \mathrm{~mL}$ distilled water. The mixture was vortex-mixed (VORTEX V-1 plus, BioSan), to ensure adequate mixing, and the absorbance was read at $510 \mathrm{~nm}$. The results were expressed as mg catechin equivalents (CEQ) per kg of honey.

\section{DPPH radical scavenging activity}

For the study, $0.75 \mathrm{ml}$ of a honey solution $(0.1 \mathrm{~g} / \mathrm{ml})$ was mixed with $1.5 \mathrm{ml}$ of warm water $\left(25^{\circ} \mathrm{C}\right)$ and $0.09 \mathrm{mg} / \mathrm{ml}$ of $\mathrm{DPPH}$ in methanol. The mixture was then incubated at temperature $25^{\circ} \mathrm{C}$ in a water bath for 5 minutes after which the absorbance was measured at wavelength $517 \mathrm{~nm}$ against a blank sample consisting of honey solution with distilled water. The absorbance of a radical blank was also measured using $0.75 \mathrm{ml}$ of distilled water.

The radical scavenging activity (RSA) of honey was expressed in terms of per-centage inhibition of DPPH radical by honey and was calculated according to the method described Batrušaityte et al., 2007 [26].

\section{Statistical Analyses}

All analyses were carried out in triplicate, and the data were expressed as mean \pm standard deviation (SD). Analysis of variance (ANOVA) was used to test for statistical significance difference between phenolic and flavonoid contents. Differences at a $95 \%(\mathrm{p}<0.05)$ confidence level were considered statistically significant. Correlations between the parameters evaluated were obtained using Pearson's correlation coefficient (r). 


\section{Results}

\subsection{Pollen Analysis}

The results of the analysis of the pollen profile of honey allow us to determine the floral origin of honey and to confirm the identity of the honey source declared by beekeepers. The International Melisopalinological Nomenclature recommends the use of four different terms to report a spectrum of pollen, namely: dominant pollen, accompanying pollen, important minor pollen and minor pollen [27] [28].

The dominant pollen is the pollen present in at least $45 \%$ of the number of counted granules, the accompanying pollen is found in smaller quantities (15\% $45 \%)$, the important minor pollen is the pollen that varies in the range of $3 \%$ $15 \%$ and the pollen that is present in the smallest amount $(>1 \%)$ is minor pollen [29] [30].

The identified pollen grains and their frequency in the analyzed honey are presented in Table 1. The size of the pollen grains in the four types of honey varied in the range $11-46 \mu \mathrm{m}$, with an average of $36 \mu \mathrm{m}$. Two types of honey (sunflower and rapeseed) are considered monofloral. For sunflower honey the dominant pollen is Helianthus spp. (49.15\% - 93.12\%) but can also be found Tilia pollen, Brassica napus (26.99\% - 30.01\%). For rapeseed honey the dominant pollen is Brassica spp. (52.17\% - 70.11\%). Mana honey and polyflora honey contain several types of pollen. Thus, four types were identified in manna honey, including: Acer platanoides (29.11\% - 30.11\%), Quercus robur (28.67\% - 29.99\%), Rubus idaeus (21.55\% - 28.78\%), Taraxacum officinale (22.21\% - 28.76\%). Polyflora honey contains: Helianthus annuus (24.91\% - 31.11\%), Brasssica napus $(23.45 \%-29.18 \%)$, Tilia $(28.95 \%-31.92 \%)$ (Table 1). It seems that data on the polynological analysis of honey in the Republic of Moldova are not available. The results obtained in this study are intended to confirm the botanical origin of the honey declared by beekeepers and, therefore, we can assume that the honey was filtered and processing correctly.

\subsection{Physico-Chemical Parameters}

Physico-chemical parameters were determined such as: color, moisture content, $\mathrm{pH}$ and free acidity.

\subsubsection{Color}

According to the results obtained for the analyzed honey samples, an obvious difference in their color intensity was observed. The color shade ranged from a lighter shade for rapeseed honey (water amber $7.66 \pm 3.002 \mathrm{~mm}$ ) to a darker color for sunflower honey and polyflora (extra light amber $34.366 \pm 2.101 \mathrm{~mm}$ and $36.04 \pm 1.115 \mathrm{~mm}$ ). The manna honey had the darkest color (dark amber $36.04 \pm 1.115 \mathrm{~mm}$ ). The color of polyflora honey in the Republic of Moldova and Romania is quite close given that the climatic and geographical conditions are quite close considering that they are neighboring countries [31]. For sunflower honey, the value of $58.11 \mathrm{~mm}$ (light amber color) is reported. For this type of 
Table 1. Botanical origin and color of the honey samples.

\begin{tabular}{|c|c|c|c|}
\hline Honey samples & Pollen type & Pfund scale (mm) & Color \\
\hline $\begin{array}{l}\text { sunflower honey } \\
\qquad(\mathrm{n}=6)\end{array}$ & $\begin{array}{c}\text { Dominant: Helianthus spp. } \\
(49.15 \%-93.12 \%) \\
\text { Other types: } \\
\text { Tilia, Brassica napus } \\
(26.99 \%-30.01 \%)\end{array}$ & $34.366 \pm 2.101$ & Extra light amber \\
\hline $\begin{array}{l}\text { rapeseed honey } \\
\quad(n=5)\end{array}$ & $\begin{array}{c}\text { Dominant: Brassica spp. } \\
(52.17 \%-70.11 \%) \\
\text { Other types: } \\
\text { Helianthus anuus } \\
(19.41 \%-28.91 \%)\end{array}$ & $7.66 \pm 3.002$ & Water amber \\
\hline $\begin{array}{l}\text { manna honey } \\
(\mathrm{n}=7)\end{array}$ & $\begin{array}{c}\text { Dominant: have not found } \\
\text { Other types: } \\
\text { Acer platanoides } \\
(29.11 \%-30.11 \%) \\
\text { Quercus robur } \\
(28.67 \%-29.99 \%) \\
\text { Rubus idaeus } \\
(21.55 \%-28.78 \%) \\
\text { Taraxacum officinale } \\
(22.21 \%-28.76 \%)\end{array}$ & $136.07 \pm 6.05$ & Dark amber \\
\hline $\begin{array}{l}\text { polyflower honey } \\
\qquad(\mathrm{n}=10)\end{array}$ & $\begin{array}{c}\text { Dominant: have not found } \\
\text { Other types: } \\
\text { Helianthus annuus } \\
(24.91 \%-33.11 \%) \\
\text { Brasssica napus } \\
(23.45 \%-29.18 \%) \\
\text { Tilia } \\
(28.95 \%-31.92 \%)\end{array}$ & $36.04 \pm 1.115$ & Extra light amber \\
\hline
\end{tabular}

honey from Romania, a value of $51 \mathrm{~mm}$ and a value of $66.7 \mathrm{~mm}$ are reported [32] for the one from Spain [33].

Based on a Pfund scale, honey can be classified by color [34]. It depends on the type of honey and certain chemical characteristics such as mineral content [35]. The transition elements in honey may form complexes with organic honey compounds that tend to be very colored and therefore affect the color of honey [36]. Changes in the color of honey occur slowly during storage or rapidly during heat treatment, as a result of the Maillard reaction [37] [38].

\subsubsection{Moisture Content}

The moisture content of all honey samples was below $20 \%$, which is in line with the standard prescribed by Council Directive 2001/110/EC. All honey samples examined had a moisture content. Mana honey contains the lowest humidity (18.0\%) while the highest humidity was observed in polyflora honey (19.4\%) (Table 2). The higher moisture content of honey can be observed when honey is harvested at the beginning of the season. The low moisture content of honey can have a protective effect against microbes, especially during long-term storage, while a higher water content can cause honey to ferment and acetic acid to form. No significant correlation was found between the moisture content and other determined properties of the analyzed honey samples. 
Table 2. Physicochemical parameters of honey samples.

\begin{tabular}{|c|c|c|c|c|}
\hline Honey samples & $\begin{array}{l}\text { Sunflower honey } \\
\qquad(\mathrm{n}=6)\end{array}$ & $\begin{array}{l}\text { Rapeseed honey } \\
\qquad(\mathrm{n}=5)\end{array}$ & $\begin{array}{l}\text { Manna honey } \\
(\mathrm{n}=7)\end{array}$ & $\begin{array}{l}\text { Polyflora honey } \\
\qquad(\mathrm{n}=10)\end{array}$ \\
\hline $\begin{array}{l}\mathrm{pH} \text { and free acidity } \\
(\mathrm{mM} / \mathrm{kg})\end{array}$ & $3.92 \pm 11.21^{\mathrm{a}}$ & $4.20 \pm 4.37^{\mathrm{b}}$ & $4.23 \pm 4.03^{\mathrm{b}}$ & $4.18 \pm 11.51^{\mathrm{a}, \mathrm{b}}$ \\
\hline $\begin{array}{l}\text { Moisture content } \\
(\mathrm{g} / 100 \mathrm{~g})\end{array}$ & $19.2 \pm 1.44^{\mathrm{a}, \mathrm{b}}$ & $18.9 \pm 0.81^{\mathrm{a}, \mathrm{b}}$ & $18.0 \pm 1.11^{\mathrm{a}, \mathrm{b}}$ & $19.4 \pm 1.71^{\mathrm{a}}$ \\
\hline $\begin{array}{l}\text { Electrical conductivity } \\
(\mu \mathrm{S} / \mathrm{cm})\end{array}$ & $371 \pm 51.01^{\mathrm{b}, \mathrm{c}}$ & $161 \pm 31.29^{b}$ & $775 \pm 11.06^{\mathrm{b}}$ & $355 \pm 41.60^{\mathrm{a}, \mathrm{b}, \mathrm{c}}$ \\
\hline HMF (mg/kg) & $8.13 \pm 3.99^{b}$ & $12.9 \pm 11.10^{b}$ & $42.11 \pm 13.09^{\mathrm{d}}$ & $11.2 \pm 7.01^{\mathrm{a}}$ \\
\hline F value & $2.21^{\text {in }}$ & $2.31^{\text {in }}$ & $2.28^{\text {in }}$ & $0.71^{\text {in }}$ \\
\hline
\end{tabular}

Note: in: insignificant $(\mathrm{p}>0.05), a-d$ : in each column different letters mean significant differences $(\mathrm{p}<$ $0.001)$.

\subsection{3. $\mathrm{pH}$ and Free Acidity}

The results obtained with reference to $\mathrm{pH}$ and free acidity are in the range of 3.92 (for sunflower honey) to 4.23 (for manna honey) which is consistent with the reported data [39].

The organic acids in the composition of honey are responsible for $\mathrm{pH}$ values between 3.5 and 5.5, the acidic environment providing protection against microbial contamination [40]. The $\mathrm{pH}$ of honey is an important parameter because an acidic $\mathrm{pH}$ inhibits both the presence and growth of microorganisms and can also influence the texture of honey, its stability and shelf life [41]. If the $\mathrm{pH}$ value increases above 7.2, then the microorganisms have a favorable environment for development and, therefore, the $\mathrm{pH}$ can be considered an indicator of microbial growth [42]. pH values help identify the botanical origin of honey [43]. Free acidity analysis is useful for assessing the freshness of honey. With the alteration of honey, the value of free acidity increases as a result of the fermentation of sugars into organic acids [44]. Thus, the free acidity depends directly on the organic acids present in honey, but also on the harvesting season, as well as on the geographical origin [45] [46].

\subsection{Electrical Conductivity}

The electrical competitiveness of the honey samples ranged from 161 to 775 $\mu \mathrm{S} / \mathrm{cm}$. Electrical conductivity is a parameter that provides information about the botanical origin of honey. The analysis of this parameter is very often used, being considered a good criterion to be able to identify the botanical origin and implicitly the purity of honey [47]. Electrical conductivity is positively correlated with ash content and acidity due to the presence of ions, acids and organic proteins [48]. The limits of this parameter specified by the standards are $500-800$ $\mu \mathrm{S} / \mathrm{cm}$ for polyflora honey and below $500 \mu \mathrm{S} / \mathrm{cm}$ for monofloral honey, with many exceptions [49], and values higher than $800 \mu \mathrm{S} / \mathrm{cm}$ are specific to manna honey [50]. It has been observed that floral honey has a lower electrical conductivity than manna honey, confirming that this parameter is a quality indicator that can be used as a means to distinguish manna honey from floral honey [51]. 


\subsection{Hydroxymethylfurfural (HMF)}

As shown in Table 2, the HMF content of the honey samples analyzed in this study ranged from a minimum of $8.13 \mathrm{mg} / \mathrm{kg}$ (sunflower honey) to a maximum of $42.11 \mathrm{mg} / \mathrm{kg}$ (manna honey). The botanical origin had a significant influence $(\mathrm{p}<0.001)$ on this parameter. The hydroxymethylfurfural (HMF) content is a parameter that indicates the degree of freshness of the honey and consequently its degree of deterioration [52]. The causes of honey spoilage could be strong or prolonged by heat treatment and inadequate storage conditions [53]. In avocado honey, the hydroxymethylfurfural content (5-HMF) meets the legal criterion (40 $\mathrm{mg} / \mathrm{kg}$ ) for all samples, which has a maximum value of $27.1 \mathrm{mg} / \mathrm{kg}$ [54]. In a study of honey samples from the state of Rio Grande do Sul (Brazil), the HMF content ranged from $0.47-22.72 \mathrm{mg} / \mathrm{kg}$ which shows that these samples were fresh because the HMF content was much below the maximum limit set in Brazil (upper limit of $60 \mathrm{mg} / \mathrm{kg}$ ) and below international standards (Codex, 2001 limit of $40 \mathrm{mg} / \mathrm{kg}$ ) [55]. In monoflare honey from Romania, it was reported that all samples analyzed were fresh and had an HMF content below $40 \mathrm{mg} / \mathrm{kg}$ [56].

\subsection{Total Phenolic and Flavonoid Contents}

The polyphenol content in the analyzed samples ranged from $38.18 \mathrm{mg} \mathrm{GAE} / \mathrm{kg}$ honey for rapeseed honey to $831.09 \mathrm{mg} \mathrm{GAE} / \mathrm{kg}$ honey for manna honey (Table 3). The functional properties of honey are related to the amount of natural antioxidants in bee pollen and floral nectar [57].

The antioxidant effects of honey are attributed to the presence of phenolic acids, flavonoids, ascorbic acid, carotenoids, catalase, peroxidases, as well as Maillard reaction products in the composition of honey [58]. In the case of Irish polyflora honey, the total polyphenol content ranged from 2.59 to $81.10 \mathrm{mg}$ GAE/100 g of honey [59]. The variation of TPC in different types of honey depends on their floral origin. In black grass honey has a higher average value for TPC $(20.12 \pm 0.55 \mathrm{mg} / 100 \mathrm{~g})$ compared to rapeseed honey [60]. The difference in values is influenced by several factors, including the geographical origin, the "purity" of the honey and the storage conditions [61].

Table 3. Total phenolic and flavonoid contents and antioxidant activity of three honey samples.

\begin{tabular}{cccc}
\hline Types of honey & $\begin{array}{c}\text { Total phenolic content } \\
(\mathrm{mg} \text { GAE/kg honey) }\end{array}$ & $\begin{array}{c}\text { Total flavonoid content } \\
(\mathrm{mg} \text { QUE/kg honey) }\end{array}$ & $\begin{array}{c}\text { DPPH scavenging } \\
\text { activity \% }\end{array}$ \\
\hline $\begin{array}{c}\text { sunflower honey } \\
(\mathbf{n}=6)\end{array}$ & $42.81 \pm 11.06^{\mathrm{a}}$ & $134.19 \pm 8.11^{\mathrm{a}}$ & $18.16 \pm 1.02^{\mathrm{a}}$ \\
$\begin{array}{c}\text { rapeseed honey } \\
(\mathbf{n}=5)\end{array}$ & $38.18 \pm 3.27^{\mathrm{a}}$ & $28.41 \pm 11.72^{\mathrm{a}}$ & $16.03 \pm 0.91^{\mathrm{a}}$ \\
$\begin{array}{c}\text { manna honey } \\
(\mathrm{n}=7)\end{array}$ & $831.09 \pm 21.19^{\mathrm{b}}$ & $151.72 \pm 11.05^{\mathrm{c}, \mathrm{d}}$ & $72.03 \pm 1.17^{\mathrm{b}}$ \\
$\begin{array}{c}\text { polyflora honey } \\
(\mathbf{n}=10)\end{array}$ & $89.99 \pm 9.12^{\mathrm{a}}$ & & \\
\hline
\end{tabular}

Note: $a-d$ : in each column different letters mean significant differences $(\mathrm{p}<0.05)$. 
The flavonoid content in the analyzed honey samples ranged from $28.41 \mathrm{mg}$ QUE/kg honey for rapeseed honey to $151.72 \mathrm{mg}$ QUE/kg honey for manna honey (Table 3). Honey flavonoids can come from pollen, nectar or propolis [62]. They have a low molecular weight and are vital components for the aroma of honey and its antioxidant properties [63].

\subsection{DPPH}

The values of the antioxidant activity obtained in the analyzed honey samples were between $16.03 \%$ (for rapeseed honey) and $72.03 \%$ (for manna honey). The DPPH method with the stable organic radical 1,1-diphenyl-2-picrylhydrazyl is used to determine the free radical scavenging activity. DPPH radical inhibition activity is a parameter that varied significantly $(\mathrm{p}<0.001)$ depending on the botanical origin of the analyzed honey samples. In the case of honey samples from other geographical regions, values of $33.4 \%-85.5 \%$ were reported for honey from Tabasco [64]; for honey in Lithuania, the DPPH values are between $31.1 \%$ and $86.9 \%$. It is worth mentioning that high values are characteristic for honey in Romania. Serbian sunflower honey has values between $33.18 \%$ and $40.18 \%$ [65]. The activity of inhibiting DPPH radicals in rapeseed honey from Slovakia was reported by $11.76 \%$, and in the same type of honey from Poland it was $21.21 \%[66]$.

\subsection{Correlation between Parameters}

In order to establish the possible relationship between the studied parameters, a correlation matrix was created presented in Table 4.

According to the Pearson correlation coefficients (Table 4), an extremely high correlation was observed between TPC and DPPH, suggesting that TPC had the greatest influence on the antioxidant activity of the examined honey samples.

Table 4. Pearson's correlation coefficients for color and physico-chemical parameters, antioxidant activity, flavonoids, phenolic compounds in honey samples.

\begin{tabular}{cccccccccc}
\hline & Color & HMF & MC & FA & pH & EC & DPPH & TFC & TPC \\
\hline Color & 1 & & & & & & & \\
HMF & -0.562591 & 1 & & & & & & \\
MC & 0.026051 & -0.185017 & 1 & & & & & & \\
FA & 0.998361 & 0.712842 & 0.058919 & 1 & & & & & \\
pH & 0.998244 & -0.52899 & -0.02219 & 0.987711 & 1 & & & \\
EC & 0.999411 & -0.62307 & -0.00861 & 0.989674 & 0.999001 & 1 & & & \\
DPPH & 0.996113 & -0.62111 & -0.065156 & 0.969611 & 0.999510 & 0.999233 & 1 & & \\
TFC & 0.997743 & -0.61302 & 0.0948 & 0.95567 & 0.999831 & 0.989001 & 0.999933 & 1 & \\
TPC & 0.997511 & -0.50011 & -0.04084 & 0.99997 & 0.999003 & 0.997103 & 0.99602 & 0.99121 & 1 \\
\hline
\end{tabular}


Pearson's correlation between color, hydroxymethylfurfural (HMF), moisture content (MC), free acidity (FA), $\mathrm{pH}$, electrical conductivity (EC), antioxidant activity (DPPH), total flavonoid content (TFC), total phenolic content (TPC).

\section{Conclusion}

Each type of honey has a distinct taste and aroma and the presented results of the physico-chemical analyses show a great variability between the types of honey analyzed. Monofloral honeys are considered a more valuable class of honey, often obtaining higher prices than honey mixtures. In European countries, 30\% to $50 \%$ of marketed honey is mono-floral. Polynomial analysis showed that all types of honey correspond to the declared type. However, the physico-chemical and biological parameters of manna honey activity showed that it should not be neglected. The results presented also showed that manna honey possesses an important content of phenolic compounds compared to the other honey samples investigated. Based on the results, sunflower honey, rapeseed honey, manna honey and polyflora honey have a valuable potential and can be recommended for use in the human diet as foods with valuable biological properties. The research found that honey from the south of the Republic of Moldova corresponds to the European current requirements and norms. At the same time, the analyzed manna honey has an increased biologically active value and can be included in the list of recommended honey types for export.

\section{Acknowledgements}

The study was conducted under a project entitled "Développement durable de l'apiculture: Enjeux économiques, écologiques, de développement rural et de santé publique", 2019-2021, financed by "L'Agence Universitaire de la Francophonie en Europe Centrale et Orientale".

\section{Conflicts of Interest}

The authors declare no conflicts of interest regarding the publication of this paper.

\section{References}

[1] Boncristiani, H.D., Ellis, J., Bustamante, T., Graham, J., Jack, C.B., Kimmel, C., Mortensen, A. and Schmehl, R.D. (2021) Worlad Honey Bee Health: The Global Distribution of Western Honey Bee (Apis mellifera L.). Pests and Pathogens, Bee World, 98, 2-6. https://doi.org/10.1080/0005772X.2020.1800330

[2] Greenbaum, A. and Aryana, K. (2013) Effect of Honey a Natural Sweetener with Several Medicinal Properties on the Attributes of a Frozen Dessert Containing the Probiotic Lactobacillus acidophilus. Open Journal of Medical Microbiology, 3, 95-99. https://doi.org/10.4236/ojmm.2013.32015

[3] Bueno-Costa, F.M., Zambiazi, R.C., Bohmer, B.W., Chaves, F.C., Padilha da Silva, W., Zanusso, J.T. and Dutra, I. (2016) Antibacterial and Antioxidant Activity of Honeys from the State of Rio Grande do Sul, Brazil. LWT-Food Science and Tech- 
nology, 65, 333-340. https://doi.org/10.1016/j.lwt.2015.08.018

[4] Suvro, S. (2015) Honey-The Natural Sweetener Become a Promising Alternative Therapeutic: A Review. South Indian Journal of Biological Sciences, 1, 103-114.

[5] Bonet Rosado, H. and Mata Parreño, C. (1995) Testimonios de apicultura en Epoca Ibérica. Verdolay Murcia, No. 7, 277-285.

[6] Crane, E. (2004) A Short History of Knowledge about Honey Bees (Apis) up to 1800. Bee World, 85, 6-11. https://doi.org/10.1080/0005772X.2004.11099604

[7] Hinton, J., Schouten, C., Austin, A. and Lloyd, D. (2020) An Overview of Rural Development and Small-Scale Beekeeping in Fiji. Bee World, 97, 39-44. https://doi.org/10.1080/0005772X.2019.1698104

[8] Crane, E. (Formerly Director of IBRA) (1999) Recent Research on the World History of Beekeeping. Bee World, 80, 174-186. https://doi.org/10.1080/0005772X.1999.11099453

[9] Schouten, N.C. (2021) Factors Influencing Beekeepers Income, Productivity and Welfare in Developing Countries: A Scoping Review. Journal of Apicultural Research, 60, 204-219. https://doi.org/10.1080/00218839.2020.1844464

[10] Pocol, C.B., Sedík, P., Brumă, I.S., Amuza, A. and Chirsanova, A. (2021) Organic Beekeeping Practices in Romania: Status and Perspectives towards a Sustainable Development. Agriculture, 11, Article No. 281.

https://doi.org/10.3390/agriculture11040281

[11] Zulkhairi Amin, F.A., Sabri, S., Mohammad, S.M., Ismail, M., Chan, K.W., Ismail, N., Norhaizan, M.E. and Zawawi, N. (2018) Therapeutic Properties of Stingless Bee Honey in Comparison with European Bee Honey. Advances in Pharmacological and Pharmaceutical Sciences, 2018, Article ID: 6179596.

https://doi.org/10.1155/2018/6179596

[12] Anastasiou, I.A., Eleftheriadou, I., Tentolouris, A., Samakidou, G., Papanas, N. and Tentolouris, N. (2021) Therapeutic Properties of Honey for the Management of Wounds; Is There a Role in the Armamentarium of Diabetic Foot Ulcer Treatment? Results from in Vitro and in Vivo Studies. The International Journal of Lower EXtremity Wounds. https://doi.org/10.1177\%2F15347346211026819

[13] Miguel, M.G., Antunes, M.D. and Faleiro, M.L. (2017) Honey as a Complementary Medicine. Integrative Medicine Insights, 12.

https://doi.org/10.1177\%2F1178633717702869

[14] Smaropoulos, E. and Cremers, A.N. (2020) Medical Grade Honey for the Treatment of Paediatric Abdominal Wounds: A Case Series. Journal of Wound Care, 29, 94-99. https://doi.org/10.12968/jowc.2020.29.2.94

[15] Almasaudi, S.B., El-Shitany, N.A., Abbas, A.T., Abdel-dayem, U.A., Ali, S.S., Al Jaouni, S.K., et al. (2016) Antioxidant, Anti-Inflammatory, and Antiulcer Potential of Manuka Honey against Gastric Ulcer in Rats. Oxidative Medicine and Cellular Longevity, 2016, Article ID: 3643824. https://doi.org/10.1155/2016/3643824

[16] Afrin, S., Haneefa, S., Fernandez-Cabezudo, M., Giampieri, F., AL-Ramadi, B. and Battino, M. (2020) Therapeutic and Preventive Properties of Honey and Its Bioactive Compounds in Cancer: An Evidence-Based Review. Nutrition Research Reviews, 33, 50-76. https://doi.org/10.1017/S0954422419000192

[17] Badolato, M., Carullo, G., Cione, E., Aiello, F. and Caroleo, M.C. (2017) From the Hive: Honey, a Novel Weapon against Cancer. European Journal of Medicinal Chemistry, 142, 290-299. https://doi.org/10.1016/j.ejmech.2017.07.064

[18] Ahmad, F., Seerangan, P., Mustafa, M.Z., Osman, Z.F., Abdullah, J.M. and Idris, Z. 
(2019) Anti-Cancer Properties of Heterotrigona itama sp. Honey via Induction of Apoptosis in Malignant Glioma Cells. Malaysian Journal of Medical Sciences, 26, 30-39. https://doi.org/10.21315/mjms2019.26.2.4

[19] Mustafa, M.Z., Shamsuddin, S.H., Sulaiman, S.A. and Abdullah, J.M. (2020) Anti-Inflammatory Properties of Stingless Bee Honey May Reduce the Severity of Pulmonary Manifestations in COVID-19 Infections. Malaysian Journal of Medical Sciences, 27, 165-169. https://doi.org/10.1073/pnas.2005615117

[20] Xu, X., Han, M., Li, T., Sun, W., Wang, D., Fu, B., et al. (2020) Effective Treatment of Severe COVID-19 Patients with Tocilizumab. Proceedings of the National Academy of Sciences of the United States of America, 117, 10970-10975. https://doi.org/10.1073/pnas.2005615117

[21] Kaur, J., Kaur, R. and Kaur, A. (2018) Dietary Antioxidants and Infectious Diseases. In: Singh, P., Ed., Infectious Diseases and Your Health, Springer, Singapore, 307-316. https://doi.org/10.1007/978-981-13-1577-0_16

[22] Morei, V. (2011) Bekeeping Practice Opportunity in the Context of Sustainable Development of Rural Areas. Scientific Papers Series-Management, Economic Engineering in Agriculture and Rural Development, 11, 155-160.

[23] Eremia, N., Scripnic, E., Modvala, S. and Chiriac, A. (2017) Influence of Temperature on Nectar Collection and Storage in the Hive during Honey Harvest. Animal Science Series. Lucrări Ştiințifice-Seria Zootehnie, 68, 40-44.

[24] Chuttong, B., Phongphisutthinant, R., Sringarm, K., Burgett, M. and Barth, O.M. (2018) Nutritional Composition of Pot-Pollen from Four Species of Stingless Bees (Meliponini) in Southeast Asia. In Pot-Pollen in Stingless Bee Melittology, Springer, Cham, 313-324.

[25] White, J.W. (1984) Instrumental Color Classification of Honey: Collaborative Study. Journal of Association of Official Analytical Chemists, 67, 1129-1131.

https://doi.org/10.1093/jaoac/67.6.1129

[26] Baltrusaitytè, V., Venskutonis, P.R. and Ceksterytè, V. (2007) Radical Scavenging Activity of Different Floral Origin Honey and Beebread Phenolic Extracts. Food Chemistry, 101, 502-514. https://doi.org/10.1016/j.foodchem.2006.02.007

[27] Siddiqui, A.J., Musharraf, S.G. and Choudhary, M.I. (2017) Application of Analytical Methods in Authentication and Adulteration of Honey. Food Chemistry, 217, 687-698. https://doi.org/10.1016/j.foodchem.2016.09.001

[28] Rajs, B.B., Flanjak, I., Mutić, J., Vukojević, V., Đurđić, S. and Primorac, L. (2017) Characterization of Croatian Rape (Brassica sp.) Honey by Pollen Spectrum, Physicochemical Characteristics, and Multielement Analysis by ICP-OES. Journal of AOAC International, 100, 881-888. https://doi.org/10.5740/jaoacint.17-0147

[29] Stebler, Th. (n.d.) Brassica napus. Pollen-Wiki. https://pollen.tstebler.ch/MediaWiki/index.php?title=Brassica napus

[30] Erkan Alkan, P. (2021) Pollen Analysis of Chestnut Honey in Some Provinces of the Black Sea Region, Turkey. Mellifera, 20, 18-31.

[31] Boiştean, A., Chirsanova, A., Capcanari, T. and Siminiuc, R. (2021) Evaluation of the Color as a Characterization Parameter of Honey from Tunisia, Romania and Moldova. Biotehnologii modern-soluții pentru provocările lumii contemporane 2021, Chişinău, 20-21 mai 2021, 43.

[32] Kádár, M., Juan-Borrás, M., Hellebrandova, M., Doménech, E. and Escheriche, I. (2010) Volatile Fraction Composition of Acacia (Robinia pseudoacacia) Honey from Romania. Spain and Check Republic. Bulletin of University of Agricultural 
Sciences and Veterinary Medicine Cluj-Napoca. Agriculture, 67, 259-265.

[33] Juan-Borrás, M., Domenech, E., Hellebrandova, M. and Escriche, I. (2014) Effect of Country Origin on Physicochemical, Sugar and Volatile Composition of Acacia, Sunflower and Tilia Honeys. Food Research International, 60, 86-94.

https://doi.org/10.1016/j.foodres.2013.11.045

[34] Pontis, J.A., Alves da Costa, L.A.M., Da Silva, R.S.J. and Flach, A. (2014) Color, Phenolic and Flavonoid Content, and Antioxidant Activity of Honey from Roraima, Brazil. Food Science and Technology, 34, 69-73. https://doi.org/10.1590/S0101-20612014005000015

[35] Laaroussi, H., Bouddine, T., Bakour, M., Ousaaid, D. and Lyoussi, B. (2020) Physicochemical Properties, Mineral Content, Antioxidant Activities, and Microbiological Quality of Bupleurum spinosum Gouan Honey from the Middle Atlas in Morocco. Journal of Food Quality, 2020, Article ID: 7609454. https://doi.org/10.1155/2020/7609454

[36] Harris, E.D. (2014) Minerals in Food: Nutrition, Metabolism, Bioactivity. DEStech Publications, Inc., Lancaster.

[37] Da Silva, P.M., Gauche, C., Gonzaga, L.V., Costa, A.C.O. and Fett, R. (2016) Honey: Chemical Composition, Stability and Authenticity. Food Chemistry, 196, 309-323. https://doi.org/10.1016/j.foodchem.2015.09.051

[38] Dominguez, M.A. and Centurion, M.E. (2015) Application of Digital Images to Determine Color in Honey Samples from Argentina. Microchemical Journal, 118, 110-114. https://doi.org/10.1016/j.microc.2014.08.002

[39] Cantarelli, M.A., Pellerano, R.G., Marchevsky, E.J. and Camiña, J.M. (2008) Quality of Honey from Argentina: Study of Chemical Composition and Trace Elements. Journal of the Argentine Chemical Society, 96, 33-41.

[40] Gürbüz, S., Çakici, N., Mehmetoğlu, S., Atmaca, H., Demir, T., Apan, M.A., Atmaca, O.F. and Fgüney, F. (2020) Physicochemical Quality Characteristics of Southeastern Anatolia Honey, Turkey. International Journal of Analytical Chemistry, 6, Article ID: 8810029. https://doi.org/10.1155/2020/8810029

[41] Ratiu, I.A., Al-Suod, H., Bukowska, M., Ligor, M. and Buszewski, B. (2020) Correlation Study of Honey Regarding their Physicochemical Properties and Sugars and Cyclitols Content. Molecules, 25, Article No. 34. https://doi.org/10.3390/molecules25010034

[42] Mishyna, M., Martinez, T.J-J., Chen, J., Davidovich-Pinhas, M. and Benjamin, O. (2019) Heat-Induced Aggregation and Gelation of Proteins from Edible Honey Bee Brood (Apis mellifera) as a Function of Temperature and pH. Food Hydrocolloids, 91, 117-126. https://doi.org/10.1016/j.foodhyd.2019.01.017

[43] Acquarone, C., Buera, P. and Elizalde, B. (2007) Pattern of pH and Electrical Conductivity Upon Honey Dilution as a Complementary Tool for Discriminating Geographical Origin of honeys. Food Chemistry, 101, 695-703. https://doi.org/10.1016/j.foodchem.2006.01.058

[44] Özcan, M., Arslan, D. and Ceylan, A.D. (2006) Effect of Inverted Saccharose on Some Properties of Honey. Food Chemistry, 99, 24-29.

https://doi.org/10.1016/j.foodchem.2005.07.009

[45] Groot, G.S., Aizen, M.A., Sáez, A. and Morales, C.A. (2021) Large-Scale Monoculture Reduces Honey Yield: The Case of Soybean Expansion in Argentina. Agriculture, Ecosystems \& Environment, 306, Article ID: 107203.

https://doi.org/10.1016/j.agee.2020.107203 
[46] Siok, P.K., Nyuk, L.C., Yus, A.Y., Sheau, W.T. and Lee, S.C. (2017) Classification of Entomological Origin of Honey Based on Its Physicochemical and Antioxidant Properties. International Journal of Food Properties, 20, S2723-S2738. https://doi.org/10.1080/10942912.2017.1359185

[47] Baroni, M.V., Podio, N.S., Badini, R.G., Inga, M., Ostera, H.A., Cagnoni, M. and Wunderlin, D.A. (2015) Linking Soil, Water, and Honey Composition to Assess the Geographical Origin of Argentinean Honey by Multielemental and Isotopic Analyses. Journal of Agricultural and Food Chemistry, 63, 4638-4645. https://doi.org/10.1021/jf5060112

[48] Živkov Baloš, M., Popov, N., Vidaković, S., Ljubojević Pelić, D., Milos, P., Mihaljev, Ž. and Jakšić, S. (2018) Electrical Conductivity and Acidity of Honey. Archives of Veterinary Medicine, 11, 91-101. https://doi.org/10.46784/e-avm.v11i1.20

[49] Saxena, S., Gautam, S. and Sharma, A. (2010) Physical, Biochemical and Antioxidant Properties of Some Indian Honeys. Food Chemistry, 118, 391-397. https://doi.org/10.1016/j.foodchem.2009.05.001

[50] Oroian, M. (2015) Influence of Temperature, Frequency and Moisture Content on Honey Viscoelastic Parameters-Neural Networks and Adaptive Neuro-Fuzzy Inference System Prediction. LWT-Food Science and Technology, 63, 1309-1316. https://doi.org/10.1016/j.lwt.2015.04.051

[51] Oroian, M., Amariei, S., Rosu, A. and Gutt, G. (2015) Classification of Unifloral Honeys Using Multivariate Analysis. Journal of Essential Oil Research, 27, 533-544. https://doi.org/10.1080/10412905.2015.1073183

[52] White, J.W. (1994) The Role of HMF and Diastase Assays in Honey Quality Evaluation. Bee World, 75, 104-117. https://doi.org/10.1080/0005772X.1994.11099213

[53] Önür, İ., Misra, N.N., Barba, F.J., Putnik, P., Lorenzo, J.M., Gökmen, V. and Alpas, H. (2018) Effects of Ultrasound and High Pressure on Physicochemical Properties and HMF Formation in Turkish Honey Types. Journal of Food Engineering, 219, 129-136. https://doi.org/10.1016/j.jfoodeng.2017.09.019

[54] Rodriguez, I., Camara-Martos, F., Flores, J.M. and Serrano, S. (2019) Spanish Avocado (Persea americana Mill.) Honey: Authentication Based on Its Composition Criteria, Mineral Content and Sensory Attributes. $L W T, 111,561-572$. https://doi.org/10.1016/j.lwt.2019.05.068

[55] Do Nascimento, K.S., Sattler, J.A.G., Macedo, L.F.L., González, C.V.S., De Melo, I.L.P., Da Silva, A.E. and De Almeida-Muradian, L.B. (2018) Phenolic Compounds, Antioxidant Capacity and Physicochemical Properties of Brazilian Apis Mellifera Honeys. LWT, 91, 85-94. https://doi.org/10.1016/j.lwt.2018.01.016

[56] Pauliuc, D., Ciursă, P., Ropciuc, S., Dranca, F. and Oroian, M. (2021) Physicochemical Parameters Prediction and Authentication of Different Monofloral Honeys Based on FTIR Spectra. Journal of Food Composition and Analysis, 102, Article ID: 104021. https://doi.org/10.1016/j.jfca.2021.104021

[57] Tomczyk, M., Miłek, M., Sidor, E., Kapusta, I., Litwińczuk, W., Puchalski, C. and Dżugan, M. (2020) The Effect of Adding the Leaves and Fruits of Morus alba to Rape Honey on Its Antioxidant Properties, Polyphenolic Profile, and Amylase Activity. Molecules, 25, Article No. 84. https://doi.org/10.3390/molecules25010084

[58] Sergiel, I., Pohl, P. and Biesaga, M. (2014) Characterisation of Honeys According to Their Content of Phenolic Compounds Using High Performance Liquid Chromatography/Tandem Mass Spectrometry. Food Chemistry, 145, 404-408. https://doi.org/10.1016/j.foodchem.2013.08.068

[59] Kavanagh, S., Gunnoo, J., Passos, T.M., Stout, J.C. and White, B. (2019) Physico- 
chemical Properties and Phenolic Content of Honey from Different Floral Origins and From Rural versus Urban Landscapes. Food Chemistry, 272, 66-75.

https://doi.org/10.1016/j.foodchem.2018.08.035

[60] Kaškonienè, V., Venskutonis, P.R. and Čeksterytė, V. (2010) Carbohydrate Composition and Electrical Conductivity of Different Origin Honeys from Lithuania. LWT-Food Science and Technology, 43, 801-807.

https://doi.org/10.1016/j.lwt.2010.01.007

[61] Starowicz, M., Ostaszyk, A. and Zieliński, H. (2021) The Relationship between the Browning Index, Total Phenolics, Color, and Antioxidant Activity of Polish-Originated Honey Samples. Foods, 10, Article No. 967. https://doi.org/10.3390/foods10050967

[62] Blasa, M., Candiracci, M., Accorsi, A., Piacentini, P.M. and Piatti, E. (2007) Honey Flavonoids as Protection Agents against Oxidative Damage to Human Red Blood Cells. Food Chemistry, 104, 1635-1640.

https://doi.org/10.1016/j.foodchem.2007.03.014

[63] Silva, B., Carina, B.F., Valdemiro, G.L., Fett, R., Monguilhott, D.E., Caon, T. and Costa, A.C.O. (2020) In Vitro Anti-Inflammatory Properties of Honey Flavonoids: A Review. Food Research International, 141, Article ID: 110086. https://doi.org/10.1016/j.foodres.2020.110086

[64] Araujo, D., Ruiz Pérez-Cacho, P., Serrano, S., Dios-Palomares, R. and Galán Soldevilla, H. (2020) Sensory Profile and Physico-Chemical Properties of Artisanal Honey from Zulia. Venezuela Foods, 9, 339.

[65] Mračević, D.S., Krsti, M., Lolić, A. and Ražić, S. (2020) Comparative Study of the Chemical Composition and Biological Potential of Honey from Different Regions of Serbia. Microchemical Journal, 152, Article ID: 104420.

https://doi.org/10.1016/j.microc.2019.104420

[66] Tomczyk, M., Tarapatskyy, M. and Dżugan, M. (2019) The Influence of Geographical Origin on Honey Composition Studied by Polish and Slovak Honeys. Czech Journal of Food Sciences, 37, 232-238. https://doi.org/10.17221/40/2019-CJFS 